\title{
DYNAMIC ANALYSIS OF MULTI STOREY BUILDING WITH AND WITHOUT SHEAR WALL
}

\author{
Sarwan Gupta \\ Department of Civil \\ JSPM's Imperial \\ College of Engineering \\ and Research, \\ Wagholi, Maharashtra \\ India
}

\author{
Shubham Gaikar \\ Department of Civil \\ Vishwatmak Om \\ Gurudev College of \\ Engineering, \\ Shahapur, \\ Maharashtra, India
}

\author{
Kewal Patil \\ Department of Civil \\ Vishwatmak Om \\ Gurudev College of \\ Engineering, \\ Shahapur, \\ Maharashtra, India
}

\author{
Swapnil Shelar \\ Department of Civil \\ Vishwatmak Om \\ Gurudev College of \\ Engineering \\ Shahapur, \\ Maharashtra, India
}

\author{
Harshad Thakare \\ Department of Civil \\ Vishwatmak Om \\ Gurudev College of \\ Engineering, \\ Shahapur, \\ Maharashtra, India
}

\begin{abstract}
Nowadays, the number of buildings is constructed and designed according to the requirements and aesthetic viewpoints of the buildings every day. Most buildings are constructed in a certain spatial configuration, such as $\mathrm{X}$-shaped, $\mathrm{V}$-shaped, and the $\mathrm{x}$ and $y$ coordinates are not parallel to the structure. The earthquake caused more damage to the different structures of the building. The main problem is the slenderness ratio. The main purpose of this project is to compare the dynamic characteristics of buildings with different structural configurations in seismic zones and soil types. In this study, a 12-story space configuration structure was considered, and the height of $3 \mathrm{~m}$ on each floor did not exceed $36 \mathrm{~m}$, with shear walls and supports at different positions of the building. The dynamic behaviour of buildings in all seismic zones of magnitude III and on different types of soil (such as media) is studied. The structure has peripheral beams that carry RC shear walls with a thickness of $230 \mathrm{~mm}$. The response spectrum analysis was carried out by using software of ETABS version.
\end{abstract}

Keywords - Earthquake, Shear wall, Response Spectrum Analysis

\section{INTRODUCTION}

Most countries suffer from earthquake damage, which is one of the main impacts on buildings. Generally, the loads on the building are horizontal loads and vertical loads. Horizontal loads are wind loads and seismic loads. The vertical load is the self-weight and applied load of all structural members. Shear walls are the most effective way to resist lateral loads and wind, and it helps to improve the seismic response of buildings. In the past few decades, due to insufficient lateral rigidity and the strength of structural members to resist earthquakes, eventually leading to collapse, multi-storey buildings have been widely constructed. Reinforced concrete shear wall is most suitable for construction in areas prone to high earthquake zone, because it provides sufficient rigid connection between structural elements and avoids many hazards to buildings. The seismic performance of a building depends on the location of the shear wall in the building. Many research papers do not mention the exact location of the shear wall in the building to improve the maximum rigidity and strength against lateral forces.

\subsection{SHEAR WALL}

In terms of structural engineering, a shear wall is a structural system that consists of support panels (also called shear panels) to resist the influence of lateral loads acting on the structure. The shear wall is the vertical element of the horizontal force resistance system.

\subsection{FUNCTION OF SHEAR WALL}

Giving Lateral Strength to building:

Shear Wall should give parallel shear solidarity to the structure to oppose the even seismic tremor powers, wind powers and move these powers to the establishment.

\section{Giving Lateral Stiffness to building:}

Shear Walls give enormous firmness to working toward their direction, which lessens horizontal influence of the structure and consequently decreases harm to structure. 


\subsection{ADVANTAGES OF SHEAR WALL}

- Very good earthquake performance, if proper designed.

- Easy to construct.

- Minimizing earthquake damage to structural and nonstructural elements.

- Lesser lateral displacements than frames.

\subsection{LATERAL LOAD RESISTING SYSTEM}

\section{Built up Concrete Shear Wall:}

Shear divider is a best horizontal burden opposing framework in tall structure at high seismic zone regions. It is a solid cantilever divider gave in a RC outline working to give flexural solidness and solidarity to the primary individuals against seismic tremor. Development of shear divider in building is practical simply up to restricted stories. Shear divider will give unbending association among divider and casing individuals and it is typically given in lift center, step case and rather than traditional burden bearing dividers.

\section{Bracing System:}

Supporting is a generally productive and prudent sidelong burden opposing framework in tall structure both of steel or R.C edge to give better execution against tremor various kinds of bracings are accessible like single slanting propping, twofold corner to corner propping, K supporting, V-bracing and Knee supporting are accessible.

\section{OBJECTIVES OF THE STUDY}

1. To analyze the given multi storied building using response spectrum method with and without shear wall.

2. To study the behaviour of the structure under different locations of shear wall.

3. To analyze and compare the results of story drift and story displacement for with and without shear wall.

\section{METHODOLOGY}

Dynamic analysis by Response Spectrum Method of G+11 multi storey building with and without shear walls using ETABS software. Two models are considered namely shear wall and without shear wall. The shear walls are placed at corner of the building. The structure is analyzed for seismic analysis as per IS 1893:2016. Typical floor plan is shown below.

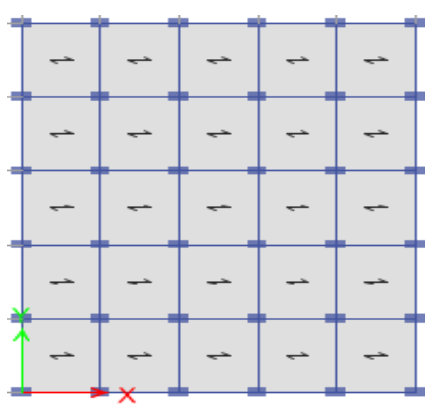

Fig 1: Building without Shear wall

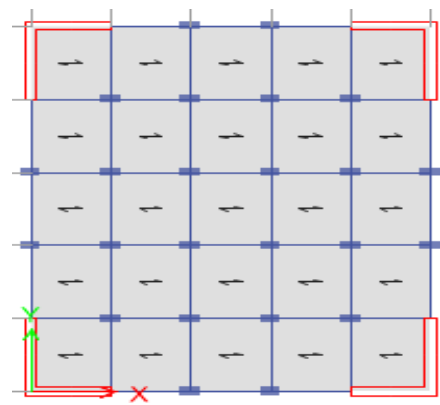

Fig 2: Building with Shear wall

\section{INPUT PARAMETERS}

Table-1: Input Parameters

\begin{tabular}{|l|c|}
\hline \multicolumn{1}{|c|}{ Particulars } & Dimensions \\
\hline Beam Size & $230 \mathrm{~mm} \mathrm{X} \mathrm{450mm}$ \\
\hline Column Size & $230 \mathrm{~mm} \mathrm{X} \mathrm{400mm}$ \\
\hline Spacing between the frame & $3 \mathrm{~m}$ \\
\hline Floor dimension in X-direction & $15 \mathrm{~m}$ \\
\hline Floor Dimension in Y-direction & $15 \mathrm{~m}$ \\
\hline
\end{tabular}

Table-2: Loading Conditions

\begin{tabular}{|l|c|}
\hline \multicolumn{1}{|c|}{ Load Type } & Value \\
\hline Live load on floor & $2 \mathrm{kN} / \mathrm{m}^{2}$ \\
\hline Live load on Terrace & $1.5 \mathrm{kN} / \mathrm{m}^{2}$ \\
\hline Floor Finish & $1.5 \mathrm{kN} / \mathrm{m}^{2}$ \\
\hline Water Proofing on Terrace & $3 \mathrm{kN} / \mathrm{m}^{2}$ \\
\hline
\end{tabular}

Table-3: Seismic Parameters

\begin{tabular}{|l|c|}
\hline \multicolumn{1}{|c|}{ Load Type } & Value \\
\hline Seismic Zone & III \\
\hline Zone Factor & 0.16 \\
\hline Response Reduction Factor, R & 5 \\
\hline Soil type & II, Medium \\
\hline Importance Factor & 1 \\
\hline
\end{tabular}




\section{RESULTS}

Two Parameters such as Storey Displacement and Storey Drift are compared in this study.

\section{A. Lateral Storey Displacement}

The maximum storey displacement observes for a value of shear wall due to response spectrum analysis in $\mathrm{X}$ - direction is $11.419 \mathrm{~mm}$ and without shear wall is $17.414 \mathrm{~mm}$ at the top. Therefore, a reduction up to $34.42 \%$ can be observed.

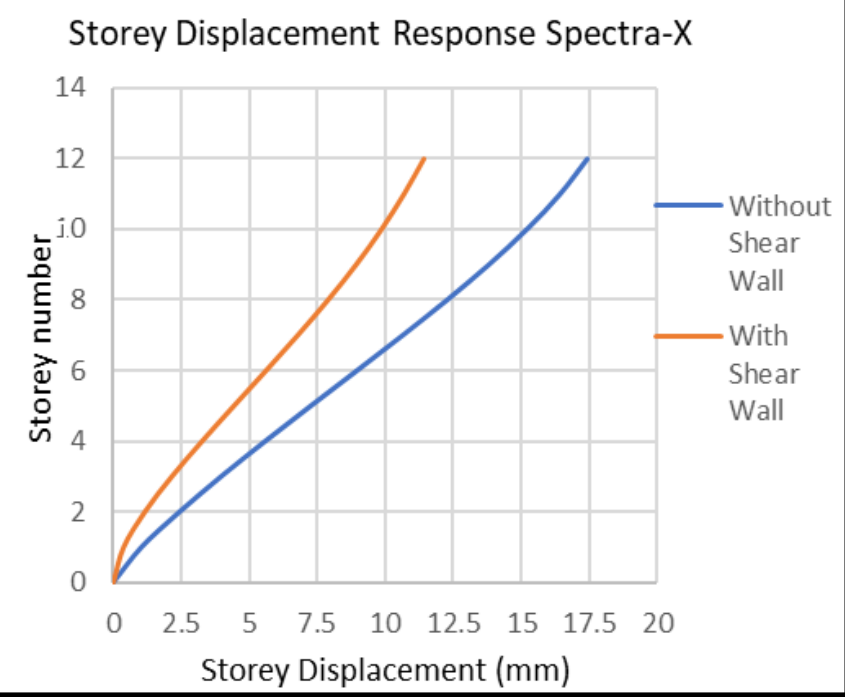

Also, the maximum storey displacement observes for a value of shear wall due response spectrum analysis in $\mathrm{Y}$ direction is $13.262 \mathrm{~mm}$ and without shear wall is $22.078 \mathrm{~mm}$ at the top. Therefore, a reduction up to $39.93 \%$ is observed.

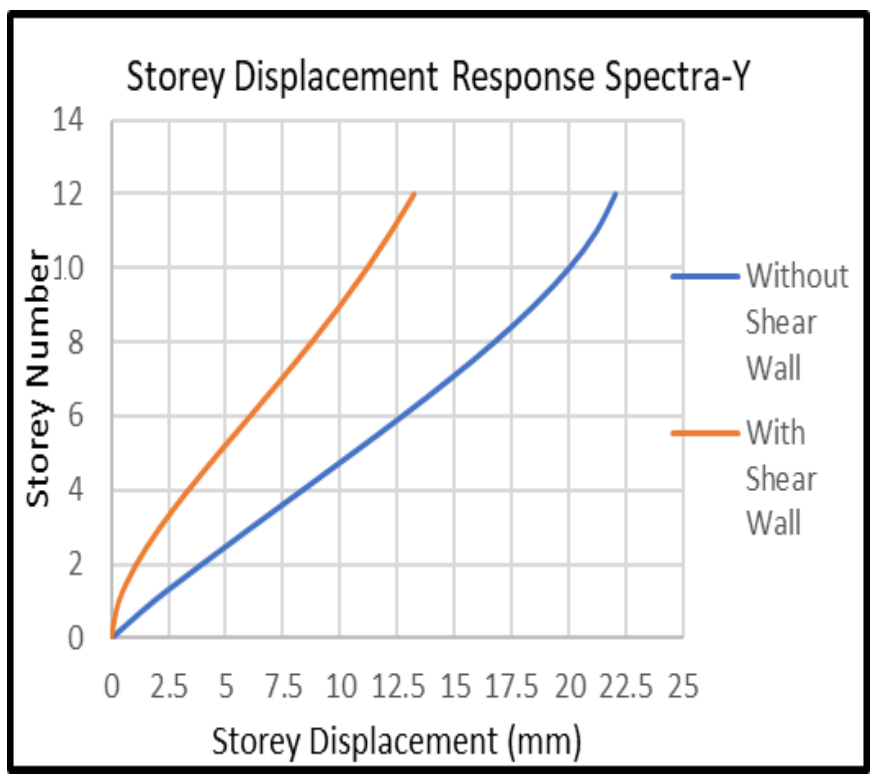

\section{B. Lateral Storey Drift}

The storey drift observes for a value of shear wall due to response spectrum analysis in X- direction is 0.000245 and without shear wall is 0.000334 at the top. Therefore, a reduction up to $26.64 \%$ is observed.

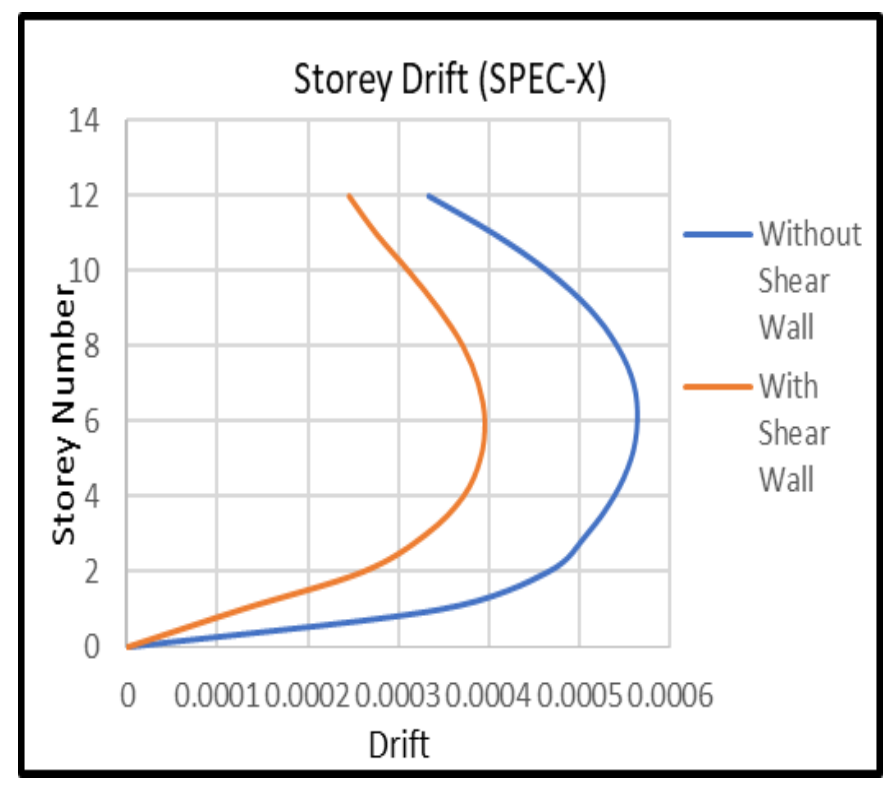

Also, the storey drift observes for a value of shear wall due to response spectrum analysis in $\mathrm{Y}$ - direction is 0.00033 and without shear wall is 0.000277 at the top. Therefore, a reduction up to $45.37 \%$ is observed.

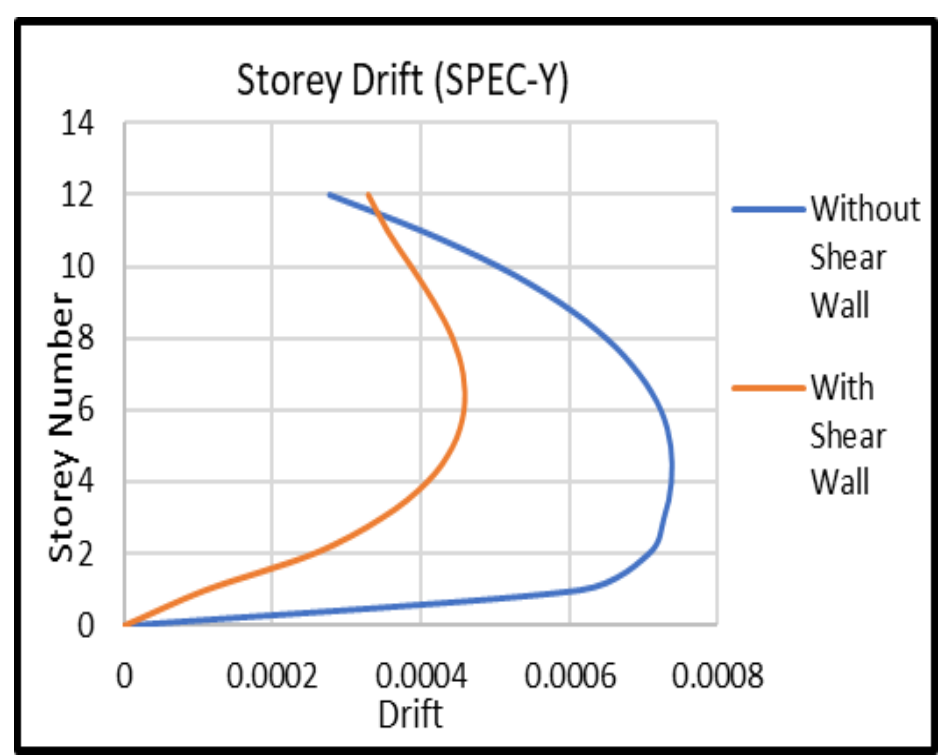

\section{CONCLUSIONS}

The following conclusions were made from the present study:

- The maximum storey displacement reduction of response spectrum analysis in X-direction is $34.42 \%$. 


\section{International Journal of Engineering Applied Sciences and Technology, 2021 \\ Vol. 6, Issue 1, ISSN No. 2455-2143, Pages 129-132 \\ Published Online May 2021 in IJEAST (http://www.ijeast.com)}

- The maximum storey displacement reduction of response spectrum analysis in Y-direction is $39.93 \%$.

- The storey drift reduction of response spectrum analysis in X-direction is $26.64 \%$.

- The storey drift reduction of response spectrum analysis in Y-direction is $45.37 \%$.

\section{REFERENCES}

[1] Mahdi H., Ahmed N. and Abdullah A. (2018), "Dynamic Analysis of Multi-Storey Building with Openings in Shear Wall" International Journal of Emerging Trends in Engineering and Development, Issue -8, Vol.5.

[2] N. Prakash, (2018), "Analysis of a multi storied building with and without shear wall" International Journal for Research in Engineering Application \& Management (IJREAM) ISSN: 2454-9150, Vol-04, Issue-03.

[3] Wadmare A., Konapure N., Lodha P. and Patil K. (2018), "Analysis of RC Structure with and without Shear Wall and Optimum Location of Shear Wall" International Research Journal of Engineering and Technology (IRJET) e-ISSN: 2395-0056, p-ISSN: 2395-0072 Volume: 05.

[4] Patil S. and Shastri L. (2017), "Dynamic Analysis of Multi Storied Building with and without Shear Wall and Bracing" GRD Journals- Global Research and Development Journal for Engineering, ISSN: 2455-5703, Volume 2, Issue 9.

[5] Mohd A., Vairagade L. and Nair V. (2015), "Comparative study on seismic analysis of multi-storey building stiffened with bracing and shear wall" International Research Journal of Engineering and Technology (IRJET) e-ISSN: 2395-0056, p-ISSN: 2395-0072 Volume: 02.

[6] Titiksh A. and Dr. Gupta M. (2015), "A Study of the Various Structural Framing Systems Subjected to Seismic Loads" SSRG International Journal of Civil Engineering (SSRG-IJCE) - volume 2.

[7] Harne V. (2015), "Comparative Study of Strength of RC Shear Wall at Different Location on Multi-storied Residential Building" International Journal of Civil Engineering Research. ISSN 2278-3652 Volume 5, Number 4, pp. 391-400.

[8] Patil S., Mali M. and Dr. Talikoti R. (2015), "Effect of Wind Load on High Rise Structure" International Journal of Engineering and Technical Research (IJETR) ISSN: 2321-0869 (O) 2454-4698 (P), Volume-3, Issue-7.

[9] Ghalimath A.G, Waghmare Y.M, Zadbuke A.A and Chaudhari A.R. (2015), "Seismic Comparative Study of Multi-storied R.C.C Building with Shear Wall in Bare Frame and Masonry Infill Frame for Various Types of Soil and Seismic Zones" International Research Journal of Engineering and Technology (IRJET) e-ISSN: 2395 0056 p-ISSN: 2395-0072 Volume: 02 Issue: 05.
[10] Chandurkar P. and Dr. Pajgade P. (2013), "Seismic Analysis of RCC Building with and Without Shear Wall" International Journal of Modern Engineering Research (IJMER) Vol.3, Issue.3, pp-1805-1810 ISSN: 2249-6645.

[11] Bhunia D. and Ramjiyani B. (2011), "Solution of Shear Wall Location in Multi-Storey Building" International journal of civil and structural engineering Volume 2, No 2, ISSN 0976 - 4399.

[12] Verma S. K., Lal R. and Kumar R. (2014), "Seismic response of RC framed buildings" International journal of civil and structural engineering, Volume 4.

[13] IS 1893 (Part-I): 2016: Criteria for Earthquake Resistance Design of Structures, New Delhi, India. 